\title{
植生群落を伴う開水路流れにおける 水面変動と流速変動の相互作用 \\ INTERACTION BETWEEN FREE SURFACE OSCILLATION AND VELOCITY FLUCTUATIONS IN OPEN-CHANNEL FLOW WITH VEGETATION ZONE
}

\author{
大本照憲 ${ }^{1} \cdot$ 田中貴幸 ${ }^{2} \cdot$ 矢北孝 $^{3}$ \\ Terunori OHMOTO, Takayuki TANAKA and Kouichi YAKITA \\ 1 正会員 工博 熊本大学教授 工学部環境システム工学科 (T860-8555 熊本市黒髪 2 丁目 39-1) \\ 2 学生会員 熊本大学大学院自然科学研究科 (同上) \\ ${ }^{3}$ 正会員 熊本大学環境システム工学科 (同上)
}

\begin{abstract}
Laboratory experiments were conducted using a two-component electromagnetic current-meter and a particle-image-velocimetry (PIV) to clarify the interaction between main flow and flexible artificial vegetation, which was attached to the central bottom of an open channel. In addition, interception plate $1 \mathrm{~mm}$ thick was placed at the one-sided vegetation interface along the main flow direction.

Results show that in the main flow region of the equilibrium state, horizontal components of the secondary currents take the directions toward the vegetation zone near the bottom and toward the non-vegetation zone near the surface. From the measurements, it was shown that this thin plate significantly suppressed water surface oscillations, horizontal periodical velocity variations and spanwise momentum transport from main flow region to vegetation zone.
\end{abstract}

Key Words : vegetation, water surface oscillations, momentum transport, transverse mixing, PIV

\section{1. はじめに}

多自然型河川工法や再自然化工法が広まる中で、中小 河川の河道計画においても植生群落が生かされる機会 はますます増えつつある.

治水や環境機能を高めるためには、植生群落の流れに 対する抵抗特性や運動量・物質の輸送特性に与える影響 について把握する事が必要である. また、植生の摇動や 水面変動は植生帯境界を通して運動量・物質の交換を促 進し、植生帯周辺における乱流構造を変化させることが 予想され、河床変動や土砂輸送にも影響することが考え られる.

植生帯を伴う流れの構造についてはこれまで多くの 研究がなされているが、その大半は側岸に植生帯を設置 した場合や、模擬植生に剛直な円柱や多孔質体が用いら れることが多く、中小河川の中央部に帯状に連なった比 較的浅い流れに見られる沈水性の植物群落を対象にし た研究事例は少ない. さらに、植生帯を伴う開水路流れ において水面変動や二次流、乱れ特性に与える影響につ

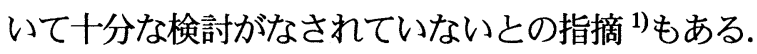

宮本ら ${ }^{2)}$ は水表面の変動を伴う流れを対象として、PIV 計測から得られた可視化断面画像を処理することによ って、瞬間的な水面形状と流速分布とを同時計測する手 法を提示し、水面変動を伴う凹部での流れの特性を明ら かにした.

著者ら ${ }^{3,4)}$ は、水路中央部に設置した有限幅の植生帯 上に越流がある場合、安定した二次流が発生し、この二 次流は乱流構造に大きな影響を与えることを指摘した. また、植生帯上が非越流の場合には、植生帯両側に発生 した水面変動は質量や運動量輸送を促進する流動性の 高い波であることを示した. さらに、水面変動と横断方 向の流速変動との相互関係から、植生帯の両境界が法線 方向の流速成分を許容するために、横断方向流速が強ま ることを予想した. しかし、植生帯を横断する流れが水 面変動や運動量輸送特性にどのような影響を及ぼすか については十分に検討がなされていない.

そこで、本研究では流れの境界条件として水路中央部 に有限幅の柔軟な模擬植生帯を設置し、さらに植生帯境 


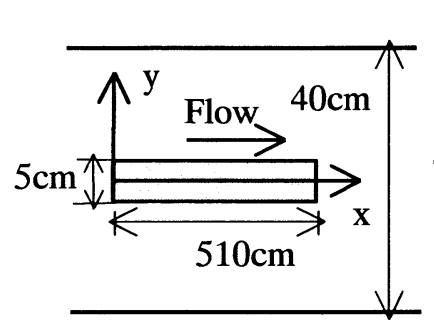

图-1 実験水路概要

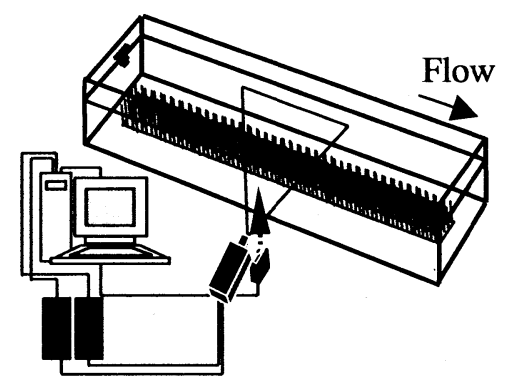

图ー2 PIV システムの概要
界面の一方には横断方向の流速成分を阻止するために 主流に平行に遮断板を直立させた.

本研究では、この遮断板は水面変動を抑制し、横断方 向の運動量輸送を制限し、流れをコントロールすること を明らかにした。

\section{2. 実䀦装置及び実験方法}

実験は長さ $10 \mathrm{~m} 、$ 幅 $40 \mathrm{~cm}$ 、高さ $20 \mathrm{~cm}$ のアクリル樹 脂からなる循環式可変勾配水路を用いて行った. 植生帯 の模型には $5 \mathrm{~cm} \times 30 \mathrm{~cm} \times 0.3 \mathrm{~cm}$ のプラスチック板に水 流の流れに追随して撓む 6.10 ナイロンブリュウスル（直 径 $0.242 \mathrm{~mm}$ 、曲け剛性 $\left.\mathrm{EI}=1.45 \times 10^{4} \mathrm{~g} \cdot \mathrm{cm}^{2}\right)$ を $\mathrm{Hv}=5.5 \mathrm{~cm}$ の高さに揃え、 $0.5 \mathrm{~cm}$ 間隔で貼り付けたものを模擬植生 帯とした. 模擬植生帯は水路上流端より $350 \mathrm{~cm}$ の位置 から $510 \mathrm{~cm}$ に渡って水路中央に設置した. 座標系は植 生帯先端の水路中央部底面を原点とし流下方向に $\mathrm{x}$ 軸、 横断方向に $\mathrm{y}$ 軸、鈆直上方に $\mathrm{z}$ 軸をとり右手系とする. またそれぞれの流速成分を u、v、w、平均值をU、V、 W、変動成分を u'、 v'、w'と表す，遮断板はアクリル製 で、厚さ $2 \mathrm{~mm}$ のものを全植生帯左岸側に垂直に立て、 上下端とも固定し、流れに対して変形しないようにした. 実験水路概要を図-1 に示す．また、表-1 のように計 4 ケースについて境界条件を設けた. なお、遮断板によ る水深の変化は非常に微小であったため、抵抗体して考 虑しないものとする.

実験は水面変動と流速の同時計測、流速の多点同時計 測を行った. 流速の単点の計測には電磁流速計を、水面 変動の計測には超音波水位計を用い、流速の多点同時計 測には面的な範囲で測定が可能である PIV (Particle

Image Velocimetry)法を用いて行った. 電磁流速計と超音
表-1 実験条件

\begin{tabular}{|l|c|c|c|c|}
\hline & $\mathrm{A} 1$ & $\mathrm{~A} 2$ & $\mathrm{~B} 1$ & $\mathrm{~B} 2$ \\
\hline 流量 $\mathrm{Q}(\mathrm{l} / \mathrm{s})$ & 5.6 & 5.6 & 12.4 & 12.4 \\
\hline 水深 $\mathrm{H}(\mathrm{cm})$ & 5 & 4.4 & 8.5 & 8.3 \\
\hline $\begin{array}{l}\text { 断面平均流速 } \\
\mathrm{Um}(\mathrm{cm} / \mathrm{s})\end{array}$ & 28.0 & 31.8 & 36.5 & 37.3 \\
\hline 遮断板の有無 & 無し & 有り & 無し & 有り \\
\hline 水路勾配 $\mathrm{I}$ & $1 / 1000$ & $1 / 1000$ & $1 / 1000$ & $1 / 1000$ \\
\hline 植生帯高さ $\mathrm{H}_{\mathrm{v}}(\mathrm{cm})$ & 5.5 & 5.5 & 5.5 & 5.5 \\
\hline 植生直径 $\mathrm{d}(\mathrm{mm})$ & 0.242 & 0.242 & 0.242 & 0.242 \\
\hline Fr 数 & 0.40 & 0.48 & 0.40 & 0.41 \\
\hline Re 数 & 12000 & 12000 & 27000 & 27000 \\
\hline
\end{tabular}

波水位計の出力信号は $100 \mathrm{~Hz}$ で、 $\mathrm{AD}$ 変換した後 1 測点 4096 個のデー夕に関して統計処理が施された.PIV（図 -2 参照）は光源に空冷式ダブルパルス YAG レーザー

（出力 $25 \mathrm{mj}$ ）を用い、シート光の厚さを $1 \mathrm{mm、パルス}$ 間隔から左岸側に向かって、緥断面の計測時には水路床 から水面に向かってレーザーを照射した. レーザー光と CCD カメラを同期させて読み込まれた可視化画像は 30fps（frame per second）、960×1018（pixel）のモノクロ ビデオ画像としてパーソナルコンピュータのハードデ イスクに記録され、PIV 法によって処理された. 流速の サンプリング周波数は $15 \mathrm{~Hz}$ 、トレーサーとして粒径 30 $\mu \mathrm{m}$ 、比重 1.02 のナイロン粒子を使用した．PIV の計測 対象領域は水平面においては $\mathrm{x}=312.5 \mathrm{~cm} \sim \mathrm{x}=320.0 \mathrm{~cm}$ 、 $\mathrm{y}=-2.5 \mathrm{~cm} \sim \mathrm{y}=-10.0 \mathrm{~cm}$ の $7.5 \mathrm{~cm} \times 7.5 \mathrm{~cm}$ とし底面付近の $\mathrm{z}=1.1 \mathrm{~cm}\left(\mathrm{z} / \mathrm{H}_{\mathrm{v}}=0.2\right)$ 、半水深付近の $\mathrm{z}=2.8 \mathrm{~cm} \quad\left(\mathrm{z} / \mathrm{H}_{\mathrm{v}}=0.5\right)$ 、 水面付近の $\mathrm{z}=4.3 \mathrm{~cm} \quad\left(\mathrm{z} / \mathrm{H}_{\mathrm{v}}=0.8\right)$ の 3 個所で、縦断面に おいては $\mathrm{y}=-3.0 \mathrm{~cm}$ で、領域は $\mathrm{x}=312.5 \mathrm{~cm} \sim \mathrm{x}=320.0 \mathrm{~cm}$ 、 $\mathrm{z}=0 \mathrm{~cm} \sim \mathrm{z}=0.9 \mathrm{Hcm}$ の $7.5 \mathrm{~cm} \times 0.9 \mathrm{Hcm}$ とし植生帯近傍の 1 個所で各ケース計測を行った. 表ー 1 に実験条件を示す.

\section{3. 実験結果}

\section{（1）水面変動と流速変動の同時計澌}

図一 3 は水面変動と流速変動の同時計測による時系列 データである. 超音波水位計を $\mathrm{x}=315.0 \mathrm{~cm} 、 \mathrm{y}=-3.0 \mathrm{~cm}$ の 植生帯境界に設置し、電磁流速計も同じ位置の $\mathrm{z}=2.5 \mathrm{~cm}$ に設置して計測を行なった. 水面変動と流速変動の周期 性について、その傾向は各々において鉛直方向に共通し たものであるため、流速変動のデー夕は植生帯の鉛直中 心付近のもので代表させた. 図-4 は水面変動と流速変 動の同時計測を行なったときの自己相関係数 4)である. 図一3、4 より、非越流型の A1 では水面変動、主流速方 

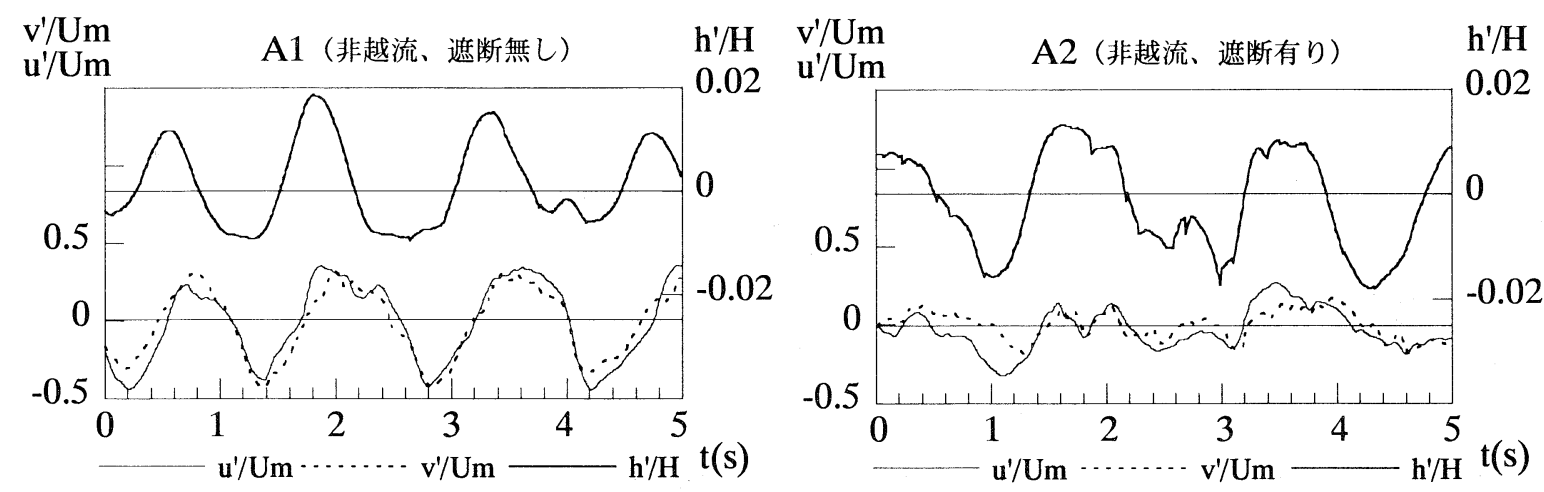

$\mathrm{h}^{\prime} / \mathrm{H}$

图-3 水面変動之流速変動の時系列

A1（非越流、遮断無し）

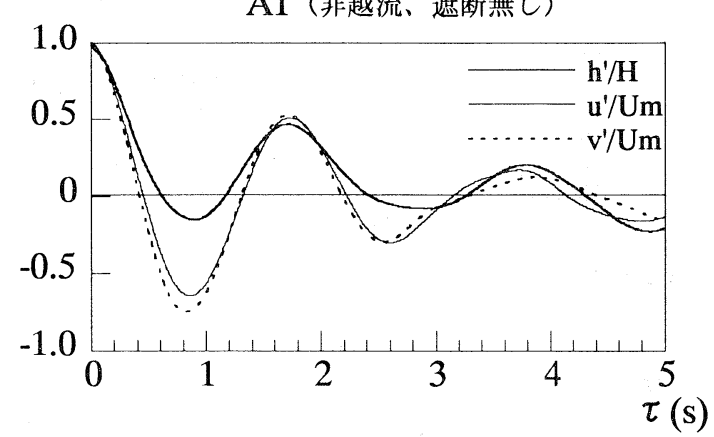

A2（非越流、遮断有り）

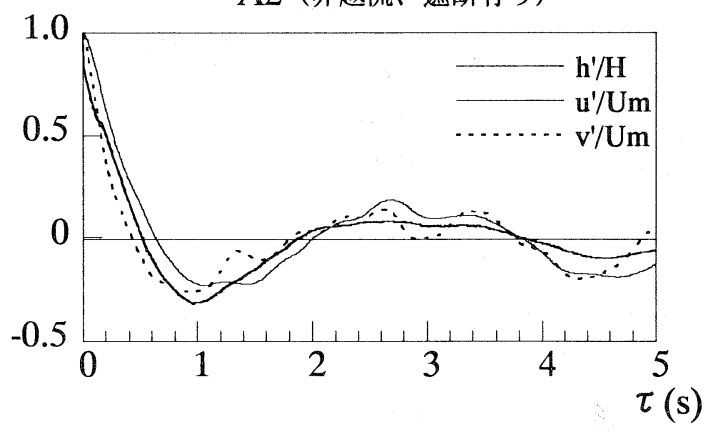

图-4 水面変動と流速変動の自己相関係数
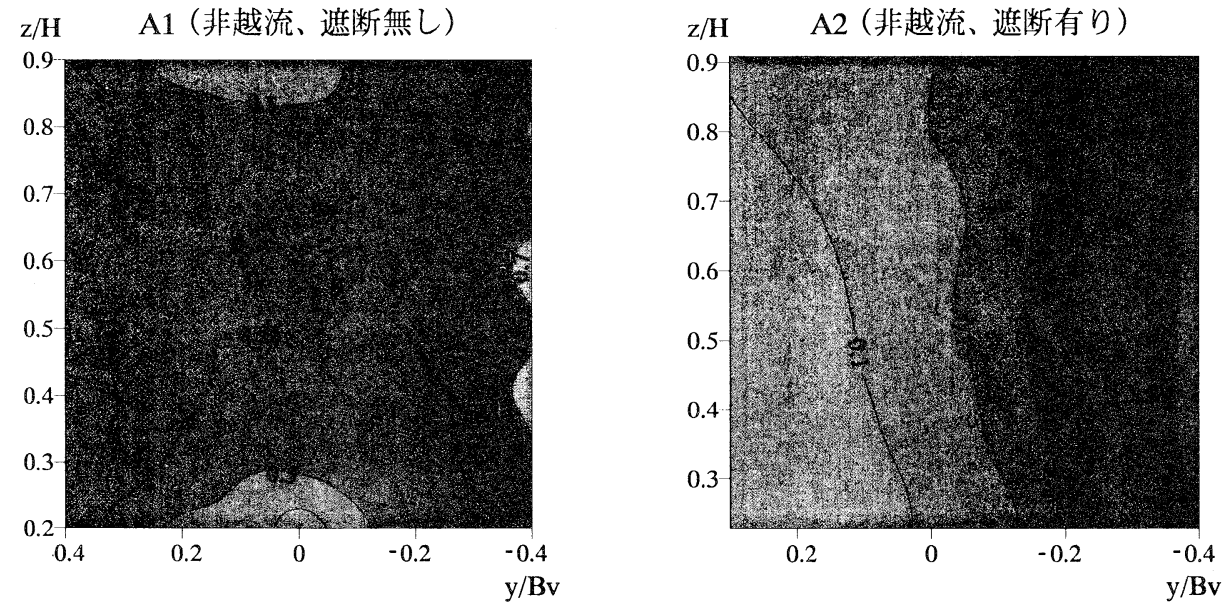

图－5 植生帯内における主流速 U/Um の等值線

向の変動成分、横断方向の流速成分の周期はサードピー クがいずれも $1.72 \mathrm{~s}$ 之同一周期で非常に高い相関をもつ. しかし、遮断板を設けた A2 では水面変動のサードピー クが 2.63 2.66s であり、A1 と比べ周期が長くなり、相 関係数も低くなっている. A2 における主流速方向の変 動成分と横断方向の流速成分においては波形が不規則 で周期の把握が困難となっている．また、その振幅は $\mathrm{A} 1$ と比較して約 50\%減少しており、遮断板による影響 が顕著に表れている.

\section{（2）平均流特性}

\section{a) 植生带内の横断面における主流速 U/Um の等值線}

図ー5に I 型電磁流速計を用いて計測した主流速 $\mathrm{U} / \mathrm{Um}$ の等值線図を示す.鉛直方向には各平均水深 $\mathrm{H}$ で、 横断方向には植生帯幅 Bv で無次元化した. 電磁流速計
は鉛直方向及び横断方向ともに $5 \mathrm{~mm}$ 間隔で計測を行っ た. その際、池田ら ${ }^{5}$ は模擬植生の一部を切り抜きピト 一管と LDA による計測を行ったが、その結果、模擬植 生を一部抜き取ることによる流れ場への影響はほとん ど無いことを示した. 本実験においても模擬植生の一部 を横断方向に抜き取った上で計測を行った.

A1 において、主流速 U/Um は植生帯中央から横断方 向に増加していき、植生帯両境界で断面平均流速の約 65 70\%で最大值を取る. そして植生帯中央から鈶直方 向には減少していき、植生帯中央の底面付近と水面付近 で断面平均流速の約 45 50\%で最小值を取る. 左岸側の 植生帯境界に遮断板がある A2 においては鉛直方向に比 べ横断方向の主流速変化が卓越しており、流れが二次元 的になっている. A2 と比較して A1 は植生帯中央部でも 主流速が大きく、非植生帯からの運動量輸送が大きいこ 

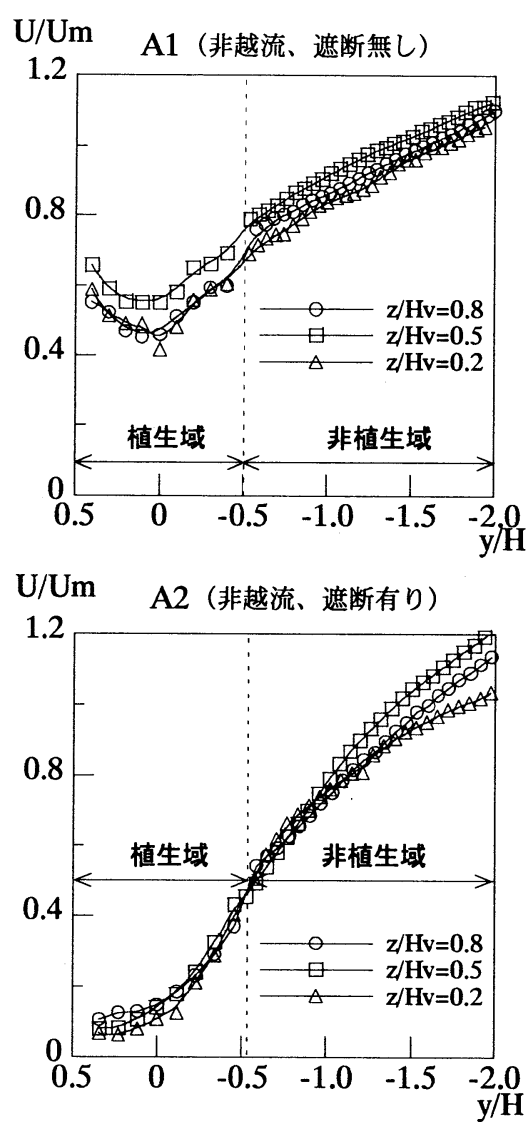

图-6 主流速 U/Um の横断方向変化 $\mathbf{u}_{\mathrm{rms}}^{\prime} / \mathrm{Um}$ A1 (非越流、遮断無し)

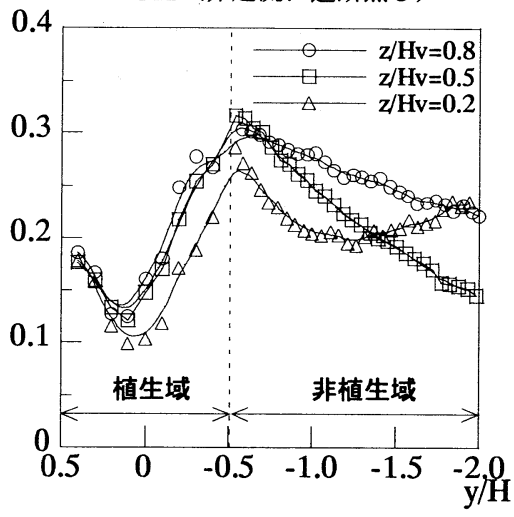

$\mathrm{u}_{\mathrm{rms}}^{\prime} / \mathrm{Um} \quad \mathrm{A} 2$ (非越流、遮断有り)

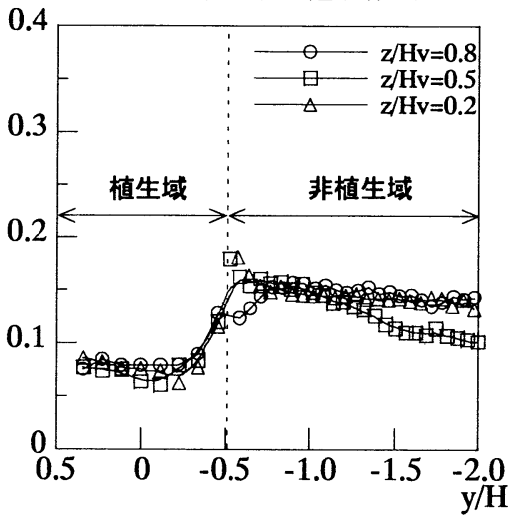

图-7 主流速の乱れ強度 $\mathrm{u}_{\mathrm{rms}}{ }_{\mathrm{rm}} / \mathrm{Um}$ の横断方向変化

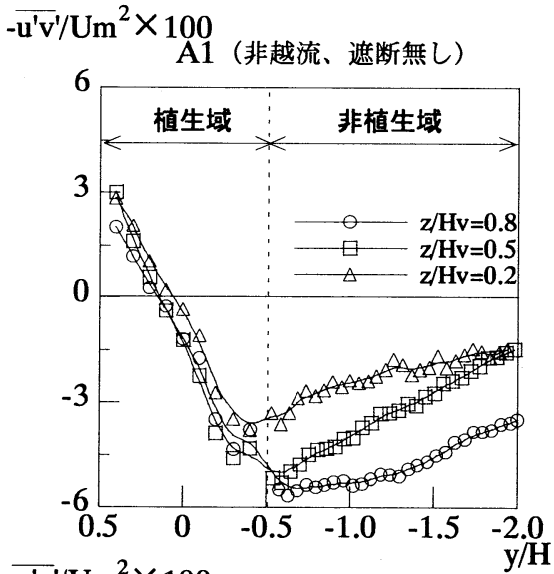

$-\mathbf{u}^{\prime} \mathbf{v}^{\prime} / \mathrm{Um}^{2} \times 100$

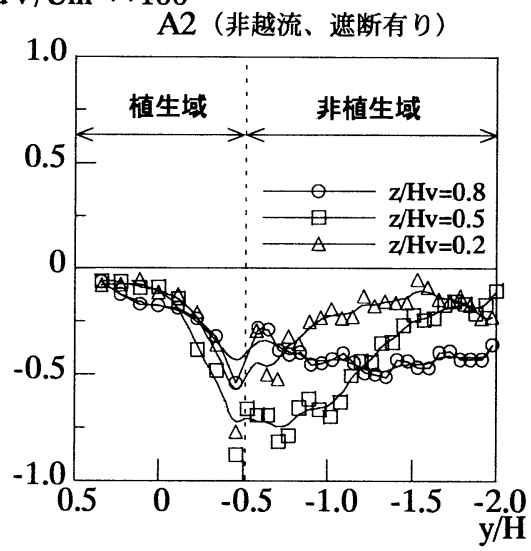

图-8レイノルズ応力- $\overline{\mathrm{u}^{\prime} \mathrm{v}^{\prime}} / \mathrm{Um}^{2}$ の横断方向変化
とが伺える.

\section{b)主流速 U/Um の横断方向变化}

図－6 は左岸側植生帯境界から主流部における主流速 U/Um の横断方向変化で、植生帯高さ $\mathrm{Hv}$ の $20 \%$ （底面 付近)、50\% (半水深付近)、80\%（水面付近）の 3 断面 を示している. 植生帯内は I 型電磁流速計で、主流部は PIV での計測である.

A1、A2 のどちらにおいても植生帯内において主流速 は急激に抑えられていることが認められる. 今回の実験 では全てのケースにおいて植生帯境界で変曲点を持つ ことが確認された.ここで、池田ら ${ }^{6}$ は植生帯境界で は主流速の横断方向分布の変曲点不安定に上って流 れが不安定となり水平組織渦が発生することを解明 し、境界で発生する周期渦について考察を行ってい る. A1 に比べ A2 では植生帯境界の変曲点における 傾きが大きく、植生帯境界付近で流速が急激に変化 していると考えられる.

\section{c)主流速の乱れ強度 $\mathbf{u}^{\prime}{ }_{\mathrm{rms}} / \mathrm{Um}$ の横断方向変化}

図-7 は左岸側植生帯境界から主流部における主流速 の乱れ強度 $\mathrm{u}_{\mathrm{m} \text { s }} \mathrm{d} \mathrm{Um}$ の横断方向変化である. $\mathrm{A} 1 、 \mathrm{~A} 2$ と もに植生帯境界で乱れ強度が著しく増大し最大值をと っている. また遮断板を用いることで乱れ強度が境界で
50\%程度減少しているのが同える. 植生を有さない開水 路流においては、乱れは壁面付近で発生し、壁面から遠 ざかるにつれて指数関数的に単調減少する. しかし、植 生帯境界域において底面から鉛直方向に乱れ強度が増 加していることが確認できる. この傾向は壁面乱流にお いては見受けられず、植生開水路流れに特有の現象とい

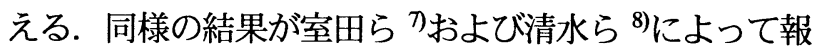
告されている.

\section{d)レイノルス応力の横断方向変化}

図－8は左岸側植生帯境界から主流部におけるレイノ

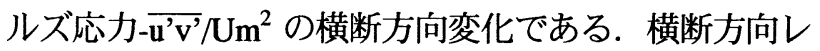
イノルズ応力- - 'v'は植生域と非植生域との運動量輸送 を考える上で重要であり、植生を有する河道設計におい て重要な水理量である. まずいずれも植生帯境界で負の 極值を取り、この位置で運動量の交換が強く行われてい ることを示している. 遮断板を設けた A2 では A1 と比 較して右岸側植生帯境界部のレイノルズ応力の極值が 約 80\%も減少していることが伺える. これにより遮断板 を設けることで非植生域と植生域との運動量輸送を抑 制していることが示唆される.このレイノルズ応力 -u'v'/Um²が最大值をとる地点は、図一6で観察されるよ うに主流速の横断方向の勾配期/ $\mathrm{y}$ が大きい領域と対応 している. つまり植生の存在によって植生内部の流速が 

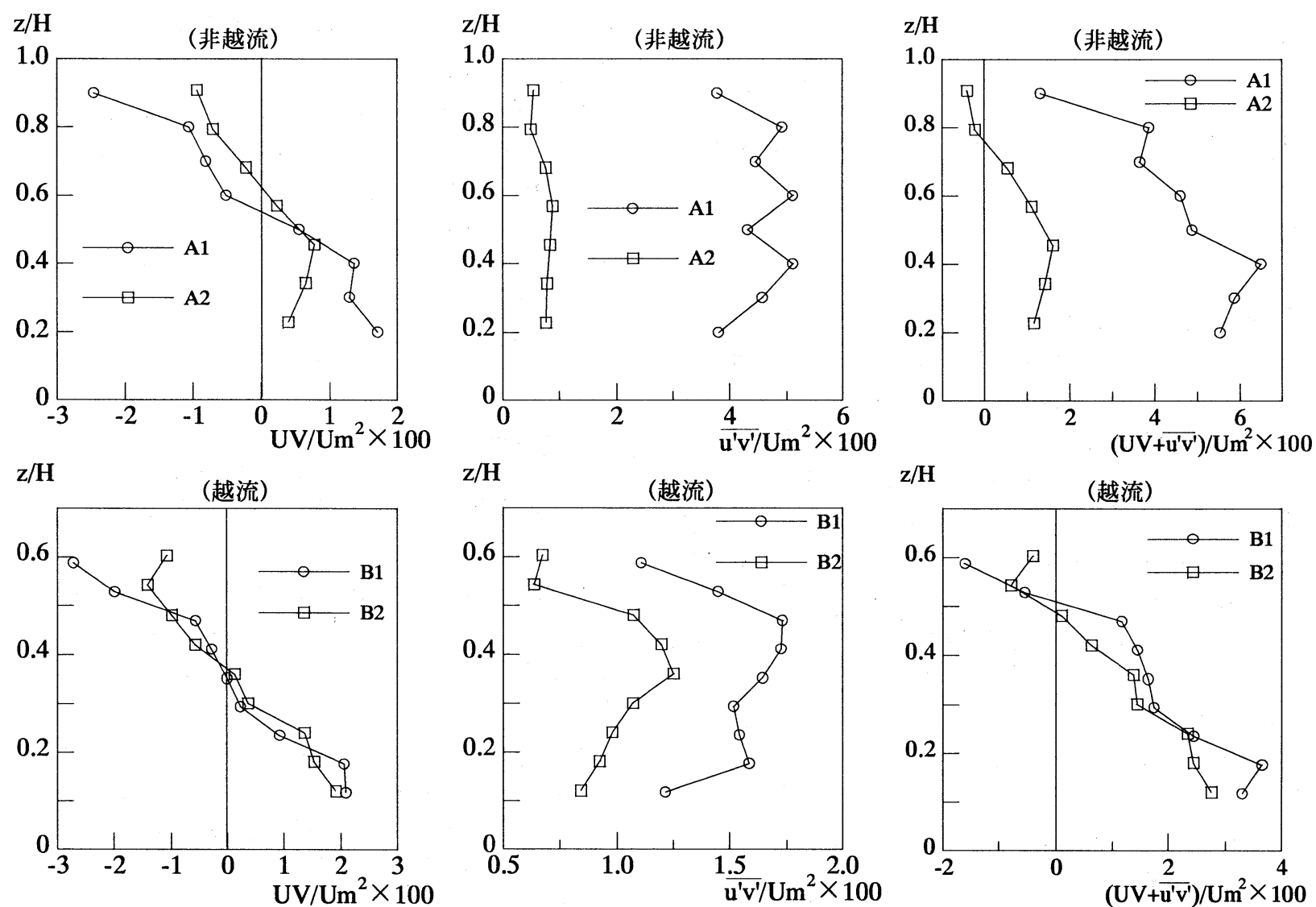

图ー9 移流による運動量輸送 $\mathrm{U} / \mathrm{Um}$ の鈶直方向変化

$\mathrm{z} / \mathrm{H}$

$\mathrm{z} / \mathrm{H}$

（越流）

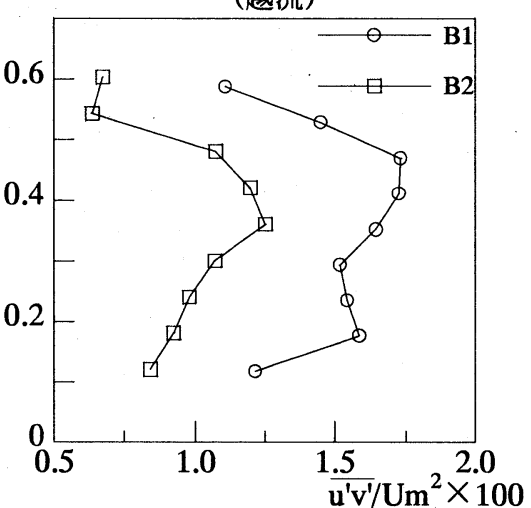

图ー10 流速変動による運動量輸送 $\overline{u^{\prime} v^{\prime}} / \mathrm{Um}^{2}$ の鈶直方向変化

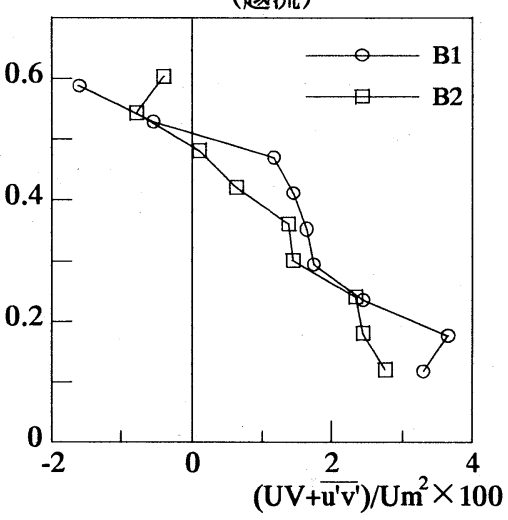

图 - 11 運動量輸送 $\left(U V+\overline{u^{\prime} v^{\prime}}\right) / \mathrm{Um}^{2}$ の鈶直方向変化
低減され、主流部との流速差によって発生する横断 方向のせん断応力のためにレイノルズ応力- $-\mathbf{u}^{\prime} \mathbf{v}^{\prime} / \mathrm{Um}^{2}$ は增加しているものと考えられる.すなわち、この 領域では激しい運動量交換が生じていることになる. ここで図ー6、7、8より、A1 の方が $\mathrm{A} 2$ より流速の空間 勾配は小さいが、乱れ強度もレイノルズ応力も大きくな っている.これは図-3、4 の相関係数から、主流速方 向の変動成分 $\mathrm{u}^{\prime}$ と横断方向の流速成分 v'の相関が $\mathrm{A} 2$ よ りも A1 が強いことによるものと考えられる.

\section{e)植生带境界における望動且堬送}

植生の摇動に伴う乱れによって運動量・物質の 交換を促進することが予想される.ここで横断方向 の運動量輸送を次式で与える.

$$
\overline{u v}=\overline{\left(U+u^{\prime}\right)\left(V+v^{\prime}\right)}=U V+\overline{u^{\prime} v^{\prime}}
$$

UV は移流による運動量輸送を、可’゙は流速変動によ る連動量輸送を示す.この 2 つの項がそれぞれのケース における植生帯境界に対してどのように輸送・交換され ているかを検討する.

図-9に植生帯境界における移流による運動量輸送の 鈶直方向変化を示す.いずれも植生高さの半分で運動量 の符号が相反していることが確認できる. 植生帯境界の 底面付近では主流部から植生帯へ運動量は運び込まれ、
水面付近では反対に植生帯から主流部へ運動量は運び 出されていることを示す. 遮断板を用いると運動量は非 越流型では減少しているが、越流型は植生高さ付近で違 いはあるもののほぼ同程度である.

図一10 は植生帯境界における流速変動による運動量 輸送の鉛直方向変化を示す. まず、どの条件においても 運動量は正の值を取っていることから流速変動による 運動量は全て植生帯内に運び込まれていることが伺え る. 遮断板を設けるといずれも運動量は減少しており、 特に非越流型では約 $80 \%$ と顕著である.これにより、遮 断板を設けることで移流による運動量輸送に比べ、流速 変動による運動量輸送に大きな影響を与えることが示 唆された.

図一11 は植生帯境界における移流による運動量輸送 と、流速変動による運動量輸送を合計した全運動量輸送 $\left(\mathrm{UV}+\overline{\mathrm{u}^{\prime} \mathrm{v}^{\prime}}\right) / \mathrm{Um}^{2}$ の鉛直方向変化である. まず非越流型で は、運動量輸送は遮断板を用いていない $\mathrm{A} 1$ の方が大き く、いずれも底面付近から増加しながら半水深付䜣で最 大值を取り水面付近に向かって減少していく. 正の值を 取っているため運動量は主流部から植生帯へと運びこ まれている. しかし、遮断板を用いた A2 では水面付近 で負の值を取っているため運動量は植生帯から主流部 へと運び込まれている. 越流型においても、底面付近か ら水面付近に向かって運動量輸送は減少していき、遮断 板を用いることによっても減少するが非越流型ほど顕 
表 -2 境界混合係数 $f$

\begin{tabular}{|c|c|c|c|c|}
\hline & A1 & A2 & B1 & B2 \\
\hline 混合係数 & 0.146 & 0.011 & 0.036 & 0.017 \\
\hline
\end{tabular}

著ではない。

\section{（3）植生带内外の混合特性}

図一6より植生帯境界において顕著な主流速の減少が 見られ、このような混合をマク口的な視点から見ると植 生帯境界でせん断応力が作用すると考えることができ る. そこで植生帯境界における混合を植生帯内外の境界 に作用するせん断応力により表現する ${ }^{9}$. 速度差のある 流体間に作用するせん断応力 $\tau_{v}$ は、一般に、式(2)で流 速差と結び付けられる ${ }^{10)}$.

$$
\tau_{v}=\rho f\left(\Delta U^{2}\right)
$$

ここに、 $\rho$ : 水の密度、 $\Delta U$ : 植生帯内外の流速差、 $f$ : 混合の強さを表す境界混合係数である.

また、 $\Delta U=U_{m}-U_{p}$ であり、 $U_{m}$ は主流部の平均流 速を表し、 $U_{p}$ は植生帯内の平均流速を表す. 境界せん 断応力 $\tau_{v}$ は図ー11 の実測デー夕を用いて算出した.

実河川で用いられている境界混合係数は、河岸に接し た樹木群の場合には約 0.03 であるのに対して、樹木群 の両側に流れのある場合では約 0.10 を標準としている 11). 遮断板の存在はこれらと対応し、遮断板が河岸と類 似の役割を果たすことが認められる.すすなわち、植生帯 の両側の流れに相互作用がある流れは、側岸に沿った植 生帯流れと本質的に異なり、運動量輸送が高まることが 実証されている.

式(2)より求めた境界混合係数 $f$ を表-2 に示す. これより、植生帯境界におけるせん断応力、すなわ ち運動量交換を境界混合係数 $f$ によって定量的に表 現することができる．植生帯を横断する流れを遮断 することで植生帯境界における運動量交換は、非越 流型では約 90\%、越流型では約 50\%の減少を示す. また運動量交換は非越流型で非常に活発であり、越 流型の運動量輸送の約 4 倍程度を示す.

\section{4. おわりに}

本研究では水路中央部に設置した植生帯を横断する 流れに注目し、遮断板を用い植生帯境界における法線方 向の流れを抑制することで、流れ場に与える水面変動や 運動量輸送について検討を行なつた. 得られた知見を列 挙すると以下のとおりである.

1) 植生帯が水路中央に設置された開水路流れにおいて、 植生帯境界の流水を遮断すると、非越流型では水面変動 の周期が長くなることが明らかになった. また、主流速
方向の流速成分と横断方向流速は周期性が弱まり、振幅 は約 50\%程度低減する。

2) 植生帯内における主流速の横断方向変化は、非越流 型において、植生帯境界に遮断板を設けると鉛直方向に 比べ横断方向の流速変化が卓越しており、二次元的とな る. また、遮断板を設けない場合は、設けた場合と比べ 植生帯中央部でも主流速が大きく、非植生帯からの運動 量輸送が大きいことが同える.

3) 植生帯が水路中央に設置された開水路流れにおいて、 遮断板を設けると植生帯境界で主流速の乱れ強度 $\mathrm{u}_{\mathrm{rms}}{ }^{\mathrm{N}} \mathrm{Um}$ は約 50\%、レイノルズ応力は約 80\%減少してい ることが伺える.これにより遮断板を設けることで非植 生域と植生域との運動量輸送を抑制していることが示 唆される.

4) 植生帯を横断する流れを遮断すると、移流による運 動量輸送に比べ、流速変動による運動量輸送に大きな影 響を与えることが認められた. それは特に非越流型で顕 著に見られる.

5) 植生帯境界における運動量輸送を境界混合係数 $f$ に よって定量的に把握することができ、遮断壁を用いると 非越流型で約 $90 \%$ 、越流型で約 50\%の低減を示す.これ は遮断板の存在によって移流に比べ流速の周期変動が 小さくなり、流速変動による運動量輸送が支配的である 非越流型の方が相対的に大きく減少することを表して いる.

\section{省考文献}

1) 螎津家久, 鬼束幸樹, 池谷和也 : 水工学論文集, 第 44 巻, pp.783-788, 2000.

2) 宮本仁志, 神田徹, 大江和正 : 水工学論文集, 第 45 巻, pp.511-516, 2001.

3) 大本照憲, 福井洋幸, 林俊一郎: 水工学論文集, 第 42 巻, pp.427-432, 2000.

4) 大本照憲, 岡本隆之: 水工学論文集、第 47 巻, pp.991-996, 2003.

5）池田俊介，金沢稔，太田賢一：土木学会論文集，No.515/ II-31, pp.33-43, 1995.

6) 池田俊介, 太田賢一, 長谷川洋: 土木学会論文集, No.443/ II -18, pp.47-54, 1992.

7) 室出明, 福原輝幸:第28 回水理講演会論文集, pp.225-230, 1984.

8）清水義彦, 辻本哲郎, 中川博次: 土木学会論文集, 第 34 巻, pp.475-480, 1991.

9）福岡捷二、藤田光一: 建設省土木研究所報告第 180 号, pp.133-141, 1990.

10) 石川忠晴ほか:第 39 回年次学術講演会, 第二部, pp.473-474, 1984.

11) 国土技術研究センター編:河道計画検討の手引き, 山海堂, pp.81-82, 2002

(2004.9. 30 受付) 